$$
\begin{aligned}
& \text { : أمراض الدواجــــن } \\
& \text { كليــــة : البطب البيطرى - جامعة أسيوط. } \\
& \text { رئيس القسم: أ.د./ ابر اهيم حسن سكر. }
\end{aligned}
$$

بعض الدراسات عن كوليرا البط في الوادى الجديد

(r)

ابر اهيم سكر، بخيت سالم، طلبه عبدالمطلب ، مختار طه، ساهر جرجس

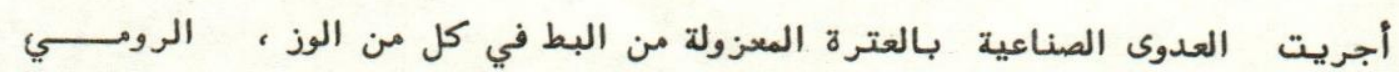

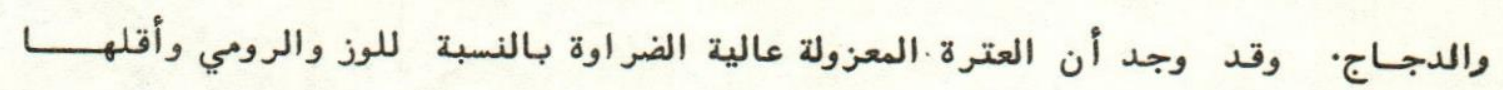

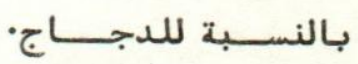

وقدوجـد أن الضراوة عالية بالنسبة للطيور المحقونه في العضل عنها في الطيــــور

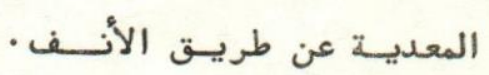

وقــــد درمت الصفة التشريحية المرضية وكذلك الميكرومكوبية للطيور المصابـــة صناعيـا على فتر ات متفاوتـه من حدوث المرض •

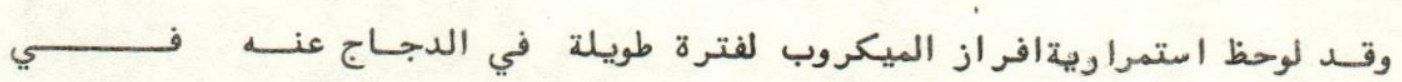

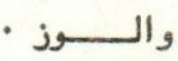
الرومســ 
1. $\log 11: \ldots$

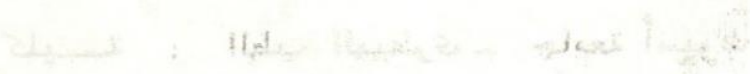

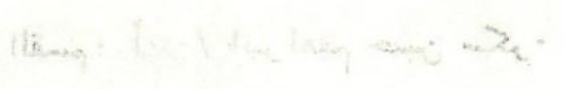

20

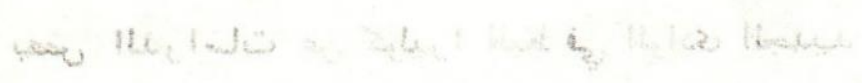

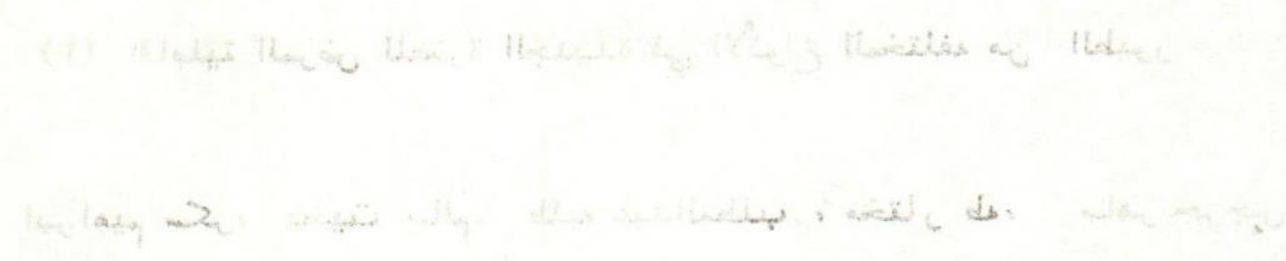

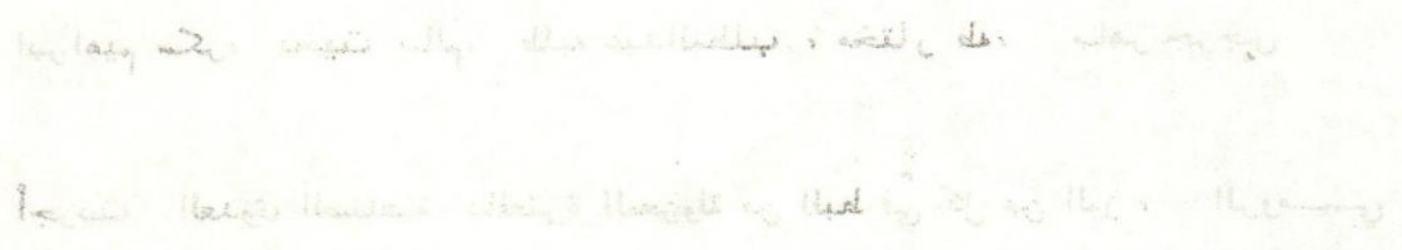

ille.e 
Dept. of Poultry Disease,

Fac. of Vet. Med., Assiut University,

Head of Dept. Prof. Dr. I.M. Sokkar.

\title{
SOME STUDIES ON DUCK PASTEURELLOSIS IN THE NEW-VALLEY \\ III. SUSCEPTIBILITY OF DIFFERENT AVIAN SPECIES \\ TO THE NEWLY ISOLATED STRAIN \\ (With One Table and 8 Figures)
}

\author{
By \\ I.M. SOKKAR, B. SALEM, T.Y. ABDEL-MOTELIB, M.M. TAHA* \\ and S.M. GERGES**
}

(Received at 15/6/1.986)

\section{SUMMARY}

\begin{abstract}
Experimental infection of geese, turkeys and chickens with the newly isolated Pasteurella multocida type " $D$ " strain of ducks showed that, this strain was highly pathogenic for geese and turkeys and to a less etent in chickens.

Per acute death's were obviously observed in the intramuscularly infected birds than those instillated in the nose.

The macro- and microscopical pictures of the disease were studied.

Continuation of dissemination of the micro-organism was more persistent in chickens than in turkey and geese.
\end{abstract}

\section{INTRODUCTION}

Experimental infection of geese, turkeys and chickens with Pasteurella multocida strain was investigated by TANIGUCHI et al. (1980), PARK (1982), HOFSTAD (1984). VAN ES and OLNEY (1940) and DONAHUE and OLSON (1971) studied the exposure method, susceptibility, pathogenicity of strain, and period of persistance of viable organism in the survivors.

Nowadays in Egypt avian pasteurellosis cause a great problem in different breeds, ages and species of birds due to the variability of serotypes, so the New-Valley strain is used for the determintion of:

1- Its pathogenicity for geese, turkeys and chickens.

2- The period of its persistance in survivors.

3- The gross and histopahological pictures of the disease in these different species.

\footnotetext{
* : Dept. f Pathology, Fac. of Vet. Med., Assiut University.

** : Abasia Res. Lab.
} 
I.M. SOKKAR, et al.

\section{MATERIAL and METHODS}

Pasteurella strain: pasteurella multocida type "D" strain was used for the experimental infection. The strain was firstly isolated by ABDEL-MOTELIB and SALEM (1986).

Birds: three groups of geese, turkeys and chickens each contained 15 birds aged from 4-6 weeks were obtained from Assiut and El-Wadi-El-Gadid poultry Farms.

Pathogenicity test: two groups of geese, turkeys and chickens (Dokki 4) each contained 6 birds in which the first group was inoculated intramuscularly and the second intranasally with $1 \mathrm{ml}$. ( $30 \times 10^{\prime}$ organism) of 6 hours pasteurella multocida type "D" strain broth culture. Three birds were left separately as controls for each species.

Before the experiment all birds proved to be free from pathogenic bacteria and parasitic infestation. The freshly dead birds of geese, turkeys and chickens were examined for macroscopic pathological changes. Specimens were also taken from the internal organs at different stages of the disease for histopathological examination Table (1). Blood films as well as re-isolation of the organism from dead birds were performed. Tracing the dissemination of the organism in survivor birds were also adopted.

\section{RESULTS}

\section{Clinical signs and Mortality:}

Signs of infections in geese, turkeys and chickens appeared in the form of depression, anorexia, ruffled feathers and increase respiratory rate in addition abnormal respiratory sound was noticed in geese. In peracute form the birds were found dead without showing any signs. the mortality rates in I.M. and I.N. infected groups of all species are illustrated in Table (1).

\section{P.M. Findings:}

On post-mortem examination of the freshly dead birds congestion of the visceral organs was a common findings, petechial and ecchymotic haemorrhages were found on coronary fat, subepicardium, pancreas as well as on the intestinal and caecal mucosa, severe congestion of $\mathrm{s} / \mathrm{c}$ blooc vessels, $\mathrm{s} / \mathrm{c}$ oedema at site of injection. In addition petechial haemorrhages on the inner side of the keel bone with presence of pin point necrotic foci on the liver were seen in turkeys. Detection of bipolarity as well as re-isolation of the organism were positive in all dead cases.

Table (1)

Showing number of dead birds at different intervals post-infection

\begin{tabular}{|c|c|c|c|c|c|c|c|c|c|c|c|}
\hline \multirow{4}{*}{$\begin{array}{l}\begin{array}{l}\text { Route of } \\
\text { inoculation }\end{array} \\
\text { Time post } \\
\text { infection }\end{array}$} & \multicolumn{3}{|c|}{ Intramuscular } & \multicolumn{8}{|c|}{ Intranasal } \\
\hline & \multirow{3}{*}{$\begin{array}{l}\text { Geese } \\
\text { after } \\
12 \text { hrs }\end{array}$} & \multirow{3}{*}{$\begin{array}{l}\text { Turkey } \\
\text { after } 12 \\
\text { hrs }\end{array}$} & \multirow{3}{*}{$\begin{array}{c}\text { Chickens } \\
\text { after } 24 \\
\text { hrs }\end{array}$} & \multicolumn{3}{|c|}{ Geese } & \multicolumn{3}{|c|}{ Turkeys } & \multicolumn{2}{|c|}{ Chickens } \\
\hline & & & & \multicolumn{6}{|c|}{$D$ a y s } & & \\
\hline & & & & 1 & 2 & 7 & 2 & 3 & 7 & 4 & 5 \\
\hline $\begin{array}{l}\text { No. of dead } \\
\text { bird }\end{array}$ & 6 & 6 & 6. & 2 & 1 & 2 & 2 & 1 & 2 & 4 & 1 \\
\hline
\end{tabular}




\section{DUCK PASTEURELLOSIS}

Dissemination of the organism:

Shedding of the viable organism persisted for 6 days in turkeys, 8 days in geese and for 15 days in chickens.

\section{Histopathological finding:}

\section{Intramuscular route of infection:}

The liver: the liver showed vascular changes in the form of congestion of the central veins, sinusoids and vessels of the portal triads some vessels showed edema of the wall, cellular infiltration of lymphoid cells and eosinophils as well as perivascular cellular reaction of lymphoid and few plasma cells. Liver edema was observed and resulted in areas of dissociation and atrophy of the hepatic cords. these changes were severe in geese and slight in turkeys and chickens. The circulating eosinophils could be demonstrated in geese and turkeys only.

The hepatic parenchyma presented disseminated arteriogenic miliary foci of variable sizes. Some foci showed cytoplasmic lysis and nuclear necrobiosis (Fig. 1). Other foci showed caseous necrosis of the hepatocytes. Colonies of the micro-organism, lymphoid cells and eosinophils were superimposed on these foci (Fig. 2). Kupffer cell proliferation was also noticed. The lytic foci were observed in geese and turkeys and were absent in chickens. The necrotic foci were observed only in turkeys.

The kidney: in the kidney, congestion and focal medullary hemorrhages were observed. These changes were severe in geese, slight in turkeys and mild in chickens. Tubulonephrosis was detected and was severe in geese and mild in turkeys and chickens (Fig. 3).

The Lung: the vascular disturbances in the lung were expressed by congestion inflammatory edema and hemorrhages in the 2 ry and 3ry bronchioles and lung alveoli (Fig. 4). Some lung vessels showed edema of the wall, cellular infiltration of lymphoid cells and few macrophages as well as perivascular cellular reaction of lymphoid cells. These vascular lesions were severe in both geese, turkeys and chickens. Eosinophils could be observed in the congested capillaries and edematous fluid in geese and turkeys.

The intestine: the intestinal layers showed edema, congestion and foci of hemorrhages. These changes were severe in geese and slight in turkeys, and chickens. In geese, atrophic catarrhal enteritis was observed which flared up to acute picture by the infecting agent. In turkeys and chickens, desquamative catarrhal enteritis was found (Fig. 5). the surface epithelium was shedded and desquamated. The intestinal wall was heavily infiltrated with lymphoid cells, macrophages and few plasma cells. Colonies of the micro-organism as well as few eosinophilic infiltration were evident.

The heart: the heart revealed only vascular alterations characterized by congestion in the myocardium and subepicardium as well as myocardial hemorrhages (Fig. 6). These changes were severe in geese and turkeys and slight in chickens. Eosinophilic infiltration in the myocardium could not be observed.

The spleen: congested spleen was seen in geese and turkeys. in the 3 species, the spleen showed free reticulo-endothelial cell macrophagal reaction of the ellipsoid. The lymphoid tissue appeared exhausted in geese and turkeys. A prominent finding in the 3 species was the presence of caseated necrotic foci involving the macrophages with superimposed colonies of the organism (Fig. 7). Circulating eosinophils could be seen only in geese.

Assiut Vet. Med. J. Vol. 17, No. 34, 1986. 
I.M. SOKKAR, et al.

\section{Intranasal route}

The parenchymatous changes in the intranasally infected groups were similar to those recorded in the intramuscularly infected groups but differed in the intensity and magnititude.

In the liver, the vascular disturbances were severe in geese died at the 1st and 2nd days post-infection and mild in geese died after 7 days. In turkeys, the changes were constant and severe. In chickens died after 4 th and 5 th days, the changes were mild. The disseminated hepatic foci were present in geese died after 1 to 2 . days and in turkeys died after 2 to 3 days, while in the dead geese at the 7 th day and in all chickens, these foci were totally absent. Eosinophilic reaction could be demonstrated only in geese after 2 and 7 days and in turkeys after 3 days.

In the lung, the vascular changes were constant and severe in the 3 species with the exception of geese died after 7 days and in chickens died after 4 days where the changes were mild. The eosinophilic reaction was observed in geese died after 1 to 2 days post-infection and in turkeys died after 3 days only. Caseous necrotic foci in the lung were observed in geese died after 1 to 2 days and in turkeys died after 3 days (Fig. 8). These necrotic foci tended to be perivascular and were adjacent to the 3ry bronchioles. They involved a wide area of the lobule and showed accumulation of eosinophiles, lymphoid cells and colonies of the micro-organism.

The examined intestine showed constant and mild vascular lesions as well as features of diffuse desquamative catarrhal enteritis. Focal atrophic catarrhal enteritis could be observed in geese died after 1 and 2 days and in chickens after 4 and 5 days. Eosinophilic reaction was noticed in the dead geese after 2 and 7 days and in turkeys after 2 days. The turkeys died after 3 days showed an incident finding of focal area of necrosis involving the muscularies and serosa with superimposed colonies of the micro-organism.

The vascular changes of the heart were mild in geese after 1 and 2 days and slight in geese after 7 days. In turkeys, the changes were severe after 2 and 7 days and slight after 3 days. In chickens, the heart showed no changes. Eosinophilic reaction was found only in geese died after 1 and 2 days.

In the spleen, congestion was found in geese after 1 and 2 days and in turkeys after 2,3 and 7 days. macrophagal reaction was constant except in geese died after 7 days. Lymphoid exhaustion was noticed in geese after 1 and 2 days and in turkeys after 2,3 and 7 days. The necrotic foci were observed in geese died after 1 and 2 days, in turkeys died after 2 , 3 and 7 days and in chickens only after 4 days.

\section{DISCUSSION}

In the present investigation the observed clinical signs of the infected birds as well as the P.M. findings of the dead birds revealed the acute septicaemic picture of the disease in all experimentally infected species.

The mortality rates in the I.M. route was $100 \%$ in all species within 24 hours post-infections while in the I.N. route the mortality rate ranged $83.3 \%$ within one week in geese and turkeys and $83.3 \%$ within 5 days in chickens. 


\section{DUCK PASTEURELLOSIS}

The isolated duck strain seemed to be highly pathogenic for geese, turkeys and chickens in both I.M. and I.N. routes. However using the I.M. route the disease exhibited a peracute . course and showed rapid deaths while in the I.N. route the disease was more protracted to acute and subacutre forms. Our findings are in agreement with VAN ES and OLNEY (1940) and TANIGUCHI et al. (1980) and Hofstad et al. (1984).

Regarding the dissemination of the micro-organism it could be concluded that chickens played a role in the transmission of the disease, as well as, geese and turkeys. TANIGUCHI et al. (1980) recorded the recovery of the organism in survivors chickens killed 8 days after inoculation.

Histợpathologically, in the intramuscular route of infection the observed vascular lesions in the parenchymatous organs (vasculitis, congestion, oedema, hemorrhages) indicated the septicaemic picture of the isolated $P$. multocida strain and the acute nature of the disease. these lesions were also recorded by MASOUD and konsoh (1963) and SIRBU et al. (1971).

The inflammatory cellular response to the infection was characterized by cellular infiltration of lymphoid, few macrophages and few plasma cells. Moreover eosinophilic reaction was demonstrated in some organs in geese and turkeys. This eosinophilic reaction could be only attributed to allergy of this strain for these species. MURATA et al. (1964) observed eosinophilic reaction in the liver of chickens infected with pasteurella strain.

The alternative changes of the isolated P. multocida strain were expressed by necrobiotic and necrotic hepatic foci in the liver and spleen desquamative enteritis and tubulonephrosis. These vascular and parenchymatous changes varied in severity in these different species. Geese showed the highest extreme while chickens showed slight alteration. This confirms that the isolated strain is highly virulent for geese, followed by turkeys and chickens are less susceptible.

In the 1.N. infected groups the same vascular and parenchymatous changes were observed, this indicate that this route induced the disease syndrome. Moreover, variance in severity of the lesions in the 3 species referred to the high susceptibility of geese followed by turkeys and chickens.

It could be concluded that the P. multocida type "D". (Duck strain) is pathogenic for geese, turkeys and chickens via both I.M. and I.N. routes. Geese showed the most severe lesions, followed by turkeys then chickens through using the two routes.

\section{REFERENCES}

Abdel El-Motelib, T.Y. and Salem, B. (1986): Some studied on duck pasteurellosis in the NewValley. 1- Characterization of a psteurella strain isolated from ducks. Assiut Vet. Med., J. Vol. 16, No. 32.

Donahue, J.M. and L.O. Olson (1971): Biochemic study of Pasteurella multocida from turkeys. Avian Dis. 16: 501 - 505.

Hofstad, M.S.; Brnes, H.J.; Calnek, B.W.; Reid, W.M. and Yoder, H.W. (1984): Avian Pasteurellosis, 8th Ed. lowa State Univ. Press, Ames, lowa, U.S.A.

Masoud, F. and Konsoh, K. (1963): An outbreak of cholera in ducks and chickens in Alexandria city. J. Arab Vet. Med. Ass. 23, 91 - 96.

Murata, M.; Horiuchi, T. and Namioka, S. (1964): Studies on the pathogenicity of pasteurella multocida for mice and chickens on the basis of O-groups. Cornell Vet. LIV, (2):
293 - 307.

Assiut Vet. Med. J. Vol. 17, No. 34, 1986. 


\section{I.M. SOKKAR, et al.}

Park, N.Y. (1982): Disseminated intravascular coagulation in experimental fow! cholera of chickens Korean Journal of veterinary research 22 (2) $211-219$.

Sirbu, Z.; Paunesca, G. and Gogoasa, V. (1971): Post-mortem, histologiçal and haematological investigation of fowls from pasteurellosis outbreaks. Revista de Zootehnis si Medicina Veterinara 21: 64 - 70.

Taniguchi, T.; Nonomura, I.; Horiuchi, T.; Takaya, M. and Akiyama, K. (1980): Pathogenicity of pasteurella multocida isolated from myna birds against chickens. Tropical Agriculture Research Center 37 - 43.

Van Es, L. and J.F. Olney (1940): An inquiry into the influence of environment on the incidence of poultry diseases. Univ. Nebraska Agr. Exp. Sta. Res. Bull. 118, pp. 17 - 21.

\section{LEGENDS}

Fig. (1): Geese liver, I.M., 12 hrs. post-infection showing necrobiotic lytic focus and superimposed colonies of Mos.

(H. E., X 25).

Fig. (2): Turkey liver, I.M., 12 hrs. post-infection, showing necrotic focus and eosinophilic reaction.

(H. E., X 40).

Fig. (3): Geese kidney, I.M., 12 hrs. post-infection, showing marked tubulonephrosis.

(H. E. X 25).

Fig. (4): Chicken lung, I.M. 24 hrs. post-infection showing severe congestion, edema and hemorrhages.

(H. E. X 25).

Fig. (5): Chickens intestine, I.M., 24 hrs. post-infection, showing desquamative catarrhal enteritis. (H. E., X 16).

Fig. (6): Geese heart, I.M., 12 hrs. post-infection showing severe myocardial hemorrhages. (H. E., X 16).

Fig. (7): Turkey spleen, I.M., 12 hrs. post-infection, showing macrophagal reaction of the ellipsoid with evidence of necrotic foci.

(H. E., X 25).

Fig. (8): Geese lung, 1.N., 2 days post-infection showing edema congestion, necrotic focus with eosinophilic reaction.

(H. E., X 40). 

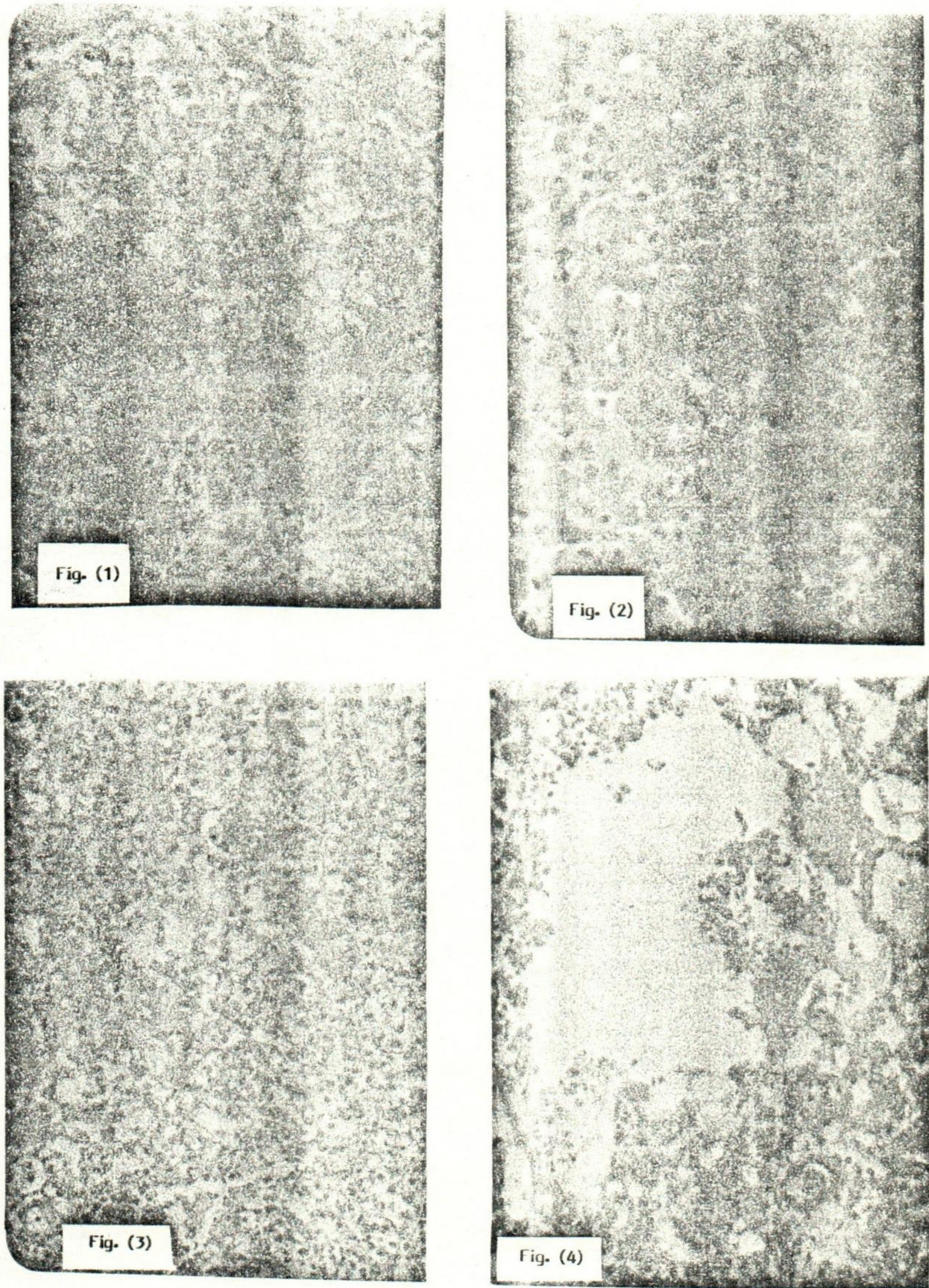


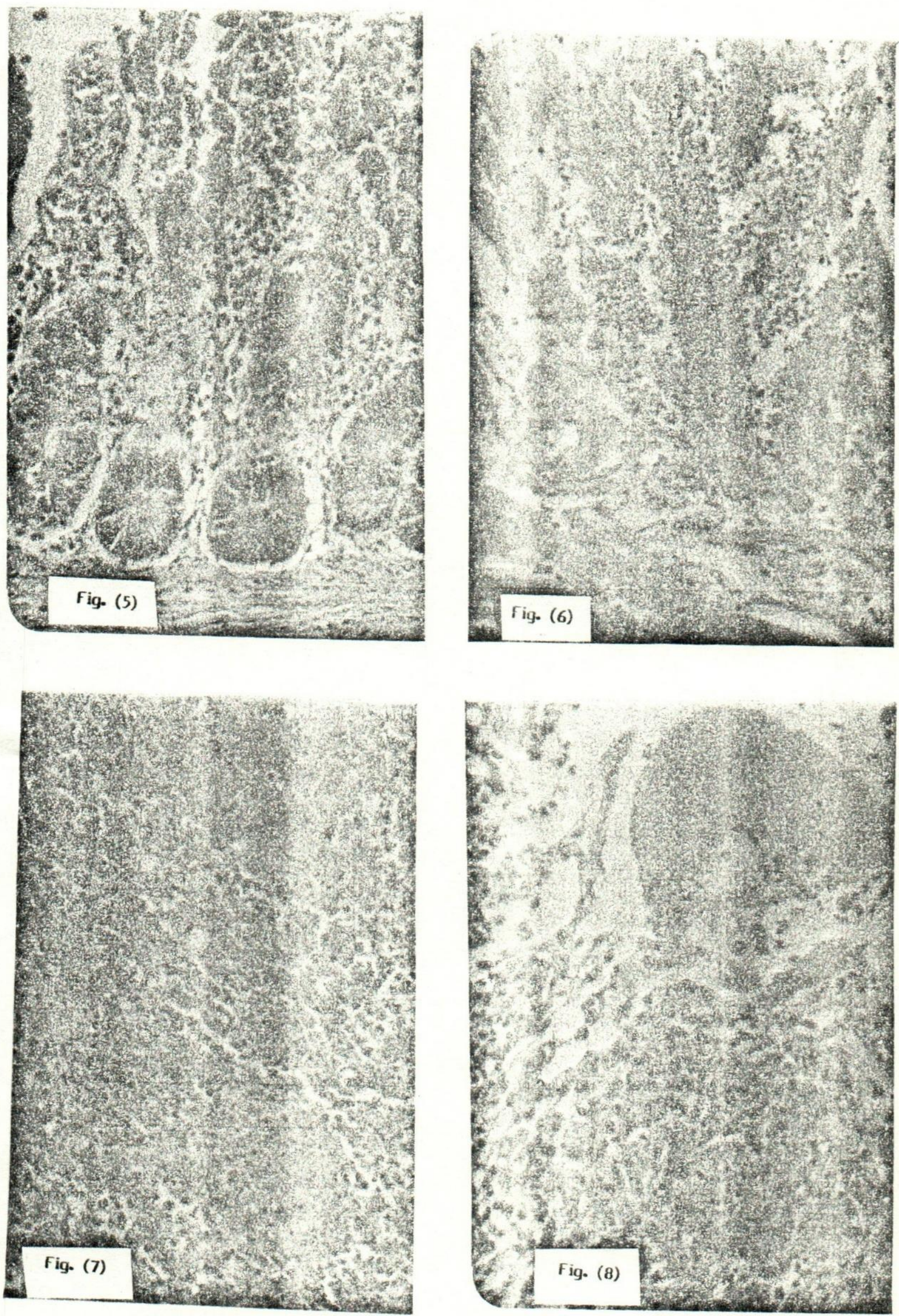
